\title{
Opportunities, Challenges, and Countermeasures of Ideological and Political in Colleges and Universities in the Era of We-Media
}

\author{
Chunming $\mathrm{Xu}^{1}$ Can Wang ${ }^{2, *}$ Nan Yang $^{3}$ \\ ${ }^{1}$ Student Development and Services Office, Dalian University of Science and Technology, Dalian, Liaoning 116052, \\ China \\ ${ }^{2}$ School of Digital Technology, Dalian University of Science and Technology, Dalian, Liaoning 116052, China \\ ${ }^{3}$ School of Economics and Management, Dalian University of Science and Technology, Dalian, Liaoning 116052, \\ China \\ *Corresponding author. Email: 652196979@qq.com
}

\begin{abstract}
The rapid development of we-media information technology has brought great opportunities for the development of ideological and political education in colleges and universities, which has updated the teaching resources of ideological and political education, enriched the teaching mode of ideological and political education, and promoted the interaction between the subject and object of ideological and political education. At the same time, it also faces the challenges of weakening the discourse authority of ideological and political educators, weakening the effectiveness of ideological and political education intermediaries, and increasing the complexity of ideological and political education. In the face of opportunities and challenges, it is an effective way to develop ideological and political education in the era of we-media to enhance the media literacy of ideological and political educators, to highlight the main role of ideological and political education objects, to embody the humanistic care of ideological and political education intermediaries, and to attach importance to the effective use of public opinion space of we-media.
\end{abstract}

Keywords: we-media, ideological and political education in colleges and universities, challenges, countermeasures

\section{OPPORTUNITIES FOR IDEOLOGICAL AND POLITICAL EDUCATION IN COLLEGES AND UNIVERSITIES IN THE ERA OF We-Media}

\subsection{The Teaching Resources Of Ideological And Political Education Were Updated}

The we-media era based on digital communication technology and network information technology has created a virtual society that is very different from the real world. The traditional ideological and political education in colleges and universities has thus entered a brand-new space, with all kinds of education and teaching resources available, and we-media has become an important channel to obtain all kinds of educational resources. At the same time, its spread and update speed is also greatly accelerated. On the one hand, because we-media breaks the time and space limit of ideological and political education, college students can choose and obtain the materials they need from it anytime and anywhere, and share the useful resources from all over the world.
According to an investigation, $25.6 \%$ of college students believe that "we-media" network can facilitate the search of learning materials, and rich and diverse resources of "we-media" have become an important resource for college students to receive education. On the other hand, in mass materials such as hot topics, red songs and inspirational stories in we-media, ideological and political educators can form useful teaching cases through selection and integration in a short time for classroom teaching, so as to update and enrich teaching resources.

\subsection{Enriching The Teaching Mode Of Ideological And Political Education}

Since the media age, as well as the main channel outside the classroom, increase the mu class, small class and other novel network autonomous learning mode, educators can use a variety of media platforms, such as the live webcast, Weibo, QQ, WeChat different ways to carry out the ideological and political education, the process is no longer just by educators single knowledge teaching and learning process, but anytime and anywhere can consciously learning process[1]. In this process, college students can receive education with relative ease and 
pleasure through a variety of we-media resources such as pictures and videos, which changes from passive preaching to active absorption and realizes teaching through lively teaching. Therefore, the era of we-media has enriched and improved the teaching mode of ideological and political education in colleges and universities.

\subsection{Promoting The Interaction Between The Subject And Object Of Ideological And Political Education}

We-media set up a platform for teachers and students to communicate, create a more harmonious and warm educational environment, draw in the distance between teachers and students, and promote equal and free two-way communication between teachers and students. College students and teachers of ideological and political theory courses can carry out one-to-one and targeted professional knowledge discussion through the bridge of "we-media". Obviously, in such an environment, students can easily talk with teachers on an equal footing, which is conducive to arousing students' enthusiasm and initiative and promoting their understanding, recognition and absorption of educational content[2].

\section{THE CHALLENGES OF IDEOLOGICAL AND POLITICAL EDUCATION IN COLLEGES AND UNIVERSITIES IN THE ERA OF We-Media}

\subsection{The Challenge Of Weakening The Discourse Authority Of Ideological And Political Educators}

In the era of we-media, everyone is a publisher of information, and everyone has a relatively free space for expression. This phenomenon virtually challenges the discourse authority of ideological and political educators. College students like to communicate with the new popular discourse in line with the social trend, namely, network discourse. On the one hand, network discourse has the characteristics of personality, trend, novelty, changeability, humor, etc., and at the same time, it also has the characteristics of randomness, difficulty in controlling and irregularity, etc. It spreads quickly and has a wide range of influence. On the other hand, the discourse of ideological and political education is generally a language symbol system that conveys the ideological and political concepts that meet the specific social requirements and serves the teaching. It has the characteristics of normative terminology, strong theoretical nature and relatively abstract language, which determines that it is not as easy to attract favor and pursuit as the network discourse, and it is in a weak position[3]. And ideological and political education workers as the use and spread of the ideological and political education discourse system, if ignored or unable to hold the characteristic of network discourse and the psychological characteristics of the audience, the result will not achieve the perfect transformation of traditional language to modern language, will lead to difficult to resonate with the educatees, even inspire their boredom and crisis of confidence, to convey the ideal effect and receive form deviation between actual effect, thereby weakening the ideological and political educators in the discourse authority.

\subsection{To Weaken The Challenge Of The Effectiveness Of Ideological And Political Education}

In the era of we-media, the application of network technology and the emergence of network virtual space require the updating of the media of ideological and political education. First of all, the original one-way passive teaching-style teaching method is no longer popular, and the free and equal, two-way interaction, pictures, pictures, audio and video teaching methods and methods are popular, which requires that the teaching methods and methods as the intermediary of ideological and political education must be updated. Secondly, in the education of ideological and political education as a dielectric body content, some content in the media environment showed a lack of depth and breadth, lack of frontier problems, performance fall after the characteristics of The Times, they failed to exceed the popularity of network communication content, but lack of explanation and leading social major issues, theoretical depth is not enough, so the content when compared with the media, content is relatively boring and abstract, so it is weakened as the ideological and political education the effectiveness of the content of the media.

\subsection{The Challenge Of Increasing The Complexity Of Ideological And Political Education}

On the one hand, it is undeniable that we-media have become more and more closely connected with people, which has enriched people's lives and brought a lot of convenience to people's study and life. However, to some extent, it has built a complex virtual environment for us. Environment and people will always interact and influence each other. Admittedly, as a kind of public opinion environment, we-media always exerts a subtle influence on college students. Firstly, under the virtual environment, college students' ideas and behaviors are influenced by various opinions all the time. The complexity and diversity 
network, timely understanding of educatees

of the virtual environment make the ideological concept of college students more and more complex, which undoubtedly increases the complexity of ideological and political education. Second, in the virtual environment of "we-media", the forms of acquiring knowledge, experience and various information are more diverse. This situation provides college students with a variety of new perspectives to see problems and makes their cognitive structures more complex and diverse, making it more difficult for educators to communicate, guide, educate and manage them. Thirdly, we-media is full of rich and diverse and bizarre information, which constantly influences and induces college students' values and value choices. This influence includes both positive and negative ones, which makes it more difficult for ideological and political education to guide them.

From the media, on the other hand, contains huge amounts of information, network society that honors to give people life and at the same time, also make some self-control is not strong group of college students get lost in the virtual world, indulgence, obsessed with dense mixed, the vast expanse of information cannot extricate oneself, cause with the real world from or even opposite, causing such as agitated, emotional ups and downs, autism and autism psychological problems. In addition, the space of "wemedia" is characterized by concealment and virtuality[4]. Some college students with weak moral sense and relatively lack of social responsibility will make irresponsible remarks out of selfishness or impulsiveness and become "keyboard men". All these behaviors mean that more manpower and more methods are needed for ideological and political education, which greatly increases the difficulty of ideological and political education.

\section{COUNTERMEASURES TO CARRY OUT IDEOLOGICAL AND POLITICAL EDUCATION IN COLLEGES AND UNIVERSITIES EFFECTIVELY IN THE ERA OF WE-MEDIA}

\subsection{Enhancing The Media Literacy Of Ideological And Political Educators}

Opinions of the CPC central committee and the state council on further strengthening and improving ideological and political education for college students points out that "ideological and political work in colleges and universities should be committed to reflecting The Times, grasping the regularity of ideological and political work, so as to continuously enhance its effectiveness". Excellent ideological and political educators should not only master the art of ideological and political education, but also adapt to the law of social development. For this purpose, the era of ideological and political education workers should be enhanced sensitivity, melt into the social media communication since the media expression of discourse system, and further summarizes their characteristics, increases the sensitivity of the language, the words of the past who out of place and the content of the rigid dogma with new, clear and concise, vivid words, further overcome and the discourse differences of college students. On the basis of adhering to the correct political direction, we should build a discourse system that is both rational and contemporary and in line with the characteristics of students' communication. At the same time, the ideological and political educators to study and try to grasp the media information technology actively, don't do network "illiterate", trying to approach students, using the media platform targeted multi-channel communication with students, with their own personality charm and have great knowledge education, guide and influence students, let them to accept exerts influence, and thus internalized as their own code of conduct, to enhance the permeability of ideological and political education, and durability.

\subsection{Highlight The Main Role Of Ideological And Political Education Objects}

Educators should change the traditional concept, treat college students equally and treat the phenomenon of discourse equivalence correctly. Educators should pay close attention to the ideological dynamics of college students, attend to their practical needs, and understand the ways and means they are willing to accept. Also should timely response to network hot spots and social phenomenon, patient, responsible, full of their life in reality and network of various ideological problems in a timely manner analysis explanation, the answer, at the same time for college students to put forward all kinds of positive encouragement and affirmation, right to described the correcting error backward ideas and guidance, for problems involving major political principles unequivocally strong-arm reaction ". The era of "wemedia" is an era in which individuality is allowed to be publicized. The teaching mode of traditional ideological and political education is not suitable for the development of The Times. As the saying goes, "education is not a simple cultural transmission, education is education, because it is a awakening of personality and soul", this is the true meaning of education[5]. Therefore, educators should respect students' subject status, support and encourage them to explore their own characteristics and potential, allowing them to within the scope of the reasonable and lawful actively express their real thoughts, to stimulate their initiative and creativity, so as to change the past, such as, by thinking, let they consciously, active ideological and political education, change passive 
learning into active learning, become external accepted as internal digestion, change ideas for action.

\subsection{Embody The Humanistic Care Of The Media Of Ideological And Political Education}

In the era of "we-media", the content of ideological and political education should not only originate from life but also be higher than life, and reflect the reality of life. But this does not mean that there is no theoretical support of the simple life, but in the vivid real material deep understanding, rational thinking after the use and beyond. First of all, ideological and political education educators should choose cases or stories close to the needs of students' real life for teaching, reduce the stay in the surface, empty and boring abstract theory, pay attention to the content of ideological and political education humanistic care. Secondly, ideological and political educators should use the discourse system of life to teach, through the renewal of discourse and expression, so that students are willing to listen, understand and accept. How to update the way of discourse expression? One is close to students' life, reflecting the sense of The Times; Second, draw the essence from the excellent traditional culture of the Chinese nation. Combine the above two effectively, and integrate the elements of traditional culture and modern culture at the same time, so as to realize the innovative development of the discourse system, so as to make the discourse system live without changing The Times and learning physics and chemistry, so as to keep the discourse advanced and scientific without losing pertinence and fresh activity.

\subsection{Attach Importance To The Effective Use Of The Space Of Public Opinion Of We-media}

In the face of some countries' direct or indirect penetration of values by virtue of their dominant position in the network, we must optimize the network virtual space and provide a clean and good education environment.

First of all, we must pay attention to the communication mode of we-media, strengthen the management of wemedia environment, build a security system, and play the role of network virtual space. Second, pay close attention to the development of college students' ideology and the media law, grasping of the features of The Times, comply with the trend of The Times, proactive, can according to students' cognitive structure and psychological characteristics in moderation, through the media platform to release some attractive, novelty and vitality of effective resources, improve the effect of education so as to achieve educational purposes. At the same time, different from general education, ideological and political education has distinct political characteristics and shoulders the task of training qualified builders and successors for the construction of the cause of socialism with Chinese characteristics. Ideological and political educators should take the initiative to use the we-media platform, persistently spread the scientific theory of marxism, actively spread the core values of socialism, effectively guide network public opinion, strengthen the position of public opinion, actively play the positive role of network virtual space, and effectively carry out ideological and political education.

\section{CONCLUSION}

"Ideological and political education is a comprehensive system, which is a controllable system composed of educators, educatees, intermediaries and environment." in the era of we-media, we must use this controllable system to effectively carry out ideological and political education by centering on various factors that restrict and influence each other. At the same time, the development of ideological and political education in colleges and universities is a gradual process, we only follow the objective law, grasp the law of The Times on the basis of the work, can promote the ideological and political education in colleges and universities to a higher and better direction.

\section{REFERENCES}

[1]Xie Tong, Opportunities, challenges and countermeasures of online ideological and political education in universities in the era of big data (ii), China newspaper industry, 2018 (7).

[2]At the national conference on ideological and political work in colleges and universities, Xi Jinping stressed that ideological and political work should be carried out throughout the whole process of education and teaching to create a new situation for the development of higher education in China, People's Daily, 2016-12-9 (1).

[3]Opinions of the CPC central committee and the state council on further strengthening and improving ideological and political education of college students ,People's Daily, 2004-10-15 (1).

[4]Yuan Yasha, Analysis on the countermeasures of ideological and political education in universities in the era of we-media, Journal of ideological and theoretical education, 2015 (11).

[5]Zhu Yinduan, Network moral education, Beijing: social sciences academic press, 2007. 